\title{
NEONATAL ADMINISTRATION OF FLUOXETINE DID NOT ALTER THE ANXIETY INDICATORS, BUT DECREASED THE LOCOMOTOR ACTIVITY IN ADULT RATS IN THE ELEVATED PLUS-MAZE
}

\author{
Valdenilson Ribeiro Ribas ${ }^{3}$, Helena Karine Rufino Aniceto', \\ Hugo André de Lima Martins ${ }^{3}$, Ketlin Helenise dos Santos Ribas', \\ Renata de Melo Guerra-Ribas ${ }^{5}$, Simone do Nascimento Fraga ${ }^{4}$, \\ Valéria Ribeiro-Ribas ${ }^{3}$, Célia Maria Mendes Vasconcelos ${ }^{6}$, \\ Marcelo Tavares Viana ${ }^{2}$, Raul Manhaes-de-Castro ${ }^{7}$
}

\begin{abstract}
The objective of this study was evaluate the anxiety and locomotor activity (LA) in 52 Wistar adult male rats, being 26 treated with fluoxetine $(10 \mathrm{mg} / \mathrm{Kg}-\mathrm{sc})$ in the neonatal period. These same rats received foot shock (FS) (1.6-mA - 2-s) in the $90^{\text {th }}$ day. The anxiety and LA were appraised by plus-maze. The time spent in the open arms was used as anxiety index and the LA was measured by number of entries in closed arms (NECA) and the total of entries (TE). T-test was used with $\mathrm{p}<0.05$ and expresses data in mean $\pm \mathrm{SEM}$. There were reductions with the fluoxetine group in the NECA $(2.35 \pm 0.33)$ and in the TE $(3.96 \pm 0.61)$ compared to the controls (4.65 \pm 0.52$)$ and $(6.96 \pm 0.94)$. The neonatal administration of fluoxetine did not alter the anxiety, but reduced the LA in the animals that received FS.
\end{abstract}

KEY WORDS: anxiety, plus-maze, serotonin, fluoxetine, neonatal.

\begin{abstract}
Administração neonatal de fluoxetina não alterou os indicadores de ansiedade, mas diminuiu a atividade locomotora em ratos adultos no labirinto elevado em cruz

Resumo - O objetivo deste estudo foi avaliar a ansiedade e a atividade locomotora (AL) em 52 ratos Wistar adultos machos, sendo 26 tratados no periodo neonatal com fluoxetina $\left(10 \mathrm{mg} / \mathrm{Kg}-\mathrm{sc}\right.$ ) e no $90^{\circ}$ dia, receberam estímulos elétricos nas patas (1,6-mA-2-s). A ansiedade e a AL foram avaliadas por meio do labirinto elevado em cruz. O tempo de permanência dos animais nos braços abertos (BA) foi utilizado como índice de ansiedade e a $A L$ medida pelo número de entradas nos braços fechados (NEBF) e pelo total de entradas (TE) nos BA e $B F$. O teste $t$ foi utilizado, $\operatorname{com}(p<0,05)$ e os dados apresentados em médiaterro padrão. Os animais tratados reduziram o $\operatorname{NEBF}(2,35 \pm 0,33)$ e o TE $(3,96 \pm 0,61)$ comparados a seus controles $(4,65 \pm 0,52)$ e $(6,96 \pm 0,94)$. A administração neonatal de fluoxetina não alterou a ansiedade, mas diminuiu a $\mathrm{AL}$ dos animais que receberam $\mathrm{EE}$.
\end{abstract}

PALAVRAS-CHAVE: ansiedade, labirinto elevado em cruz, serotonina, fluoxetina, neonatal.

The serotonin (5-hidroxytryptamine, 5-HT) controls several functions in the central nervous system?'. Animals models have contributed to demonstrate the role of serotonin in affective disorders like depression ${ }^{2,3}$, in the aggressive behavioral regulation ${ }^{4,5}$ and anxiety $y^{6,7}$. Adult rats treated with fluoxetine during the neonatal stage (days 1 to 21 , suckling period) have demonstrated behavioral alterations in the experimental models of anxiety as elevated plus-maze ${ }^{8,9}$. During the acute administration, there is an increase in extracellular serotonin in several subcorti-

Departamento de Nutrição, Universidade Federal de Pernambuco (UFPE), Recife PE, Brasil; 'Doutor em Farmacologia Experimental e Clínica da Universidade de Paris VI, Professor Adjunto do Departamento de Nutrição, UFPE; ${ }^{2}$ Doutorando em Bases Experimentais da Nutrição, Departamento de Nutrição, UFPE; ${ }^{3}$ Mestre em Neuropsiquiatria, Pós-graduação em Neuropsiquiatria e Ciências do Comportamento, UFPE; ${ }^{4}$ Mestranda em Bases Experimentais da Nutrição, Departamento de Nutrição, UFPE; ${ }^{5}$ Graduada em Nutrição, Pós-graduanda em Gestão da Qualidade e Vigilância Sanitária em Alimentos, Hospital Barão de Lucena, Recife PE (HBL); ${ }^{6}$ Graduada em Nutrição, Chefe do setor de Nutrição do HBL; ${ }^{7}$ Estagiário do Laboratório de Imunopatologia Keizo Asami LIKA, UFPE.

Received 14 May 2008, received in final form 11 September 2008. Accepted 2 October 2008.

Dr. Valdenilson Ribeiro Ribas - Avenida Armindo Moura 581 / Quadra D / Bloco 02/ Apto 201 / Conj WXL - 51130-180 Recife PE - Brasil. E-mail: ribaspsy@ufpe.br 
cal brain regions due to reuptake blockade ${ }^{10}$. In the chronic administration, there is an increase of extracellular concentrations of 5-HT at cortical and subcortical levels, and the long-term 5-HT reuptake blockade provokes desensitization of somatodendritic $5-\mathrm{HT}_{1 \mathrm{~A}}$ and terminal $5-\mathrm{HT}_{1 \mathrm{~B}}$ autoreceptors, respectively leading to a disinhibitory effect on raphe neurons firing and to reduced feedback inhibition of 5-HT release ${ }^{11,12}$. Some studies show chronic administration of selective serotonin reuptake inhibitor (SSRI) during the suckling period induces several morphologic ${ }^{13,14}$, functional $l^{15}$ and behavioral changes ${ }^{16}$. These alterations can become irreversible depending on the magnitude of the aggression ${ }^{15,17}$.

However, the data obtained in animal studies using SSRI antidepressants are contradictory ${ }^{18}$, specifically, in the effect of fluoxetine on animal models of anxiety, above all in chronic effects, using elevated plus-maze ${ }^{19}$. This is a widely used animal model of anxiety involving unconditioned responses based on exploration. Although an anxiogenic effect or lack of effect has been found in some of the studies ${ }^{8}$, anxiety evaluation in adult rodents treated with fluoxetine in neonatal period is still very scarce.

The objective of this study was test the hypothesis that the administration of a SSRI, fluoxetine, to suckling rats, promotes changes in anxiety behavior in the elevated plus-maze in adult rats.

\section{METHOD}

\section{Animals}

The animals were Wistar male rats maintained at a room temperature of $23 \pm 2{ }^{\circ} \mathrm{C}$, on a light-dark cycle of 12:12 hours (light on at 7:00 a.m.), with free access to water and food. The animals were assigned randomly to two groups (6 pups per litter) $24 \mathrm{~h}$ after birth. One group (fluoxetine group) received fluoxetine (10 $\mathrm{mg} / \mathrm{kg}, \mathrm{sc}$, dissolved in saline solution, $1 \mathrm{ml} / \mathrm{kg}$ ), and the other (control group) received an equivalent volume of saline $(\mathrm{NaCl}$, $0.9 \%$ ). The treatments were applied every day from the $1^{\text {st }}$ to the $21^{\text {st }}$ postnatal day (suckling period). Body weights were determined at 1 st to the $21^{\text {st }}$ (weaning) and $90^{\text {th }}$ day. In the end, there were 52 rats in each group.

\section{Apparatus}

A standard wooden elevated plus-maze apparatus consisting of $50 \times 10 \times 40 \mathrm{~cm}$ opposite closed arms and $50 \times 10 \mathrm{~cm}$ open arms that radiated from a central $10 \times 10 \mathrm{~cm}$ space was used. The apparatus was elevated to a height of $50 \mathrm{~cm}$ above floor level by a single support.

\section{Behavioral evaluation}

The animals aged 90 days, weighing 310-330g, were evaluated with regard to anxiety behavior and locomotor activity, using elevated plus-maze. This model is based on the innate fear rodents have for open and elevated spaces ${ }^{19,20}$. Rats on the elevated plus- maze tend to avoid the open arms and prefer to stay in the enclosed arms. When confined to the open arms, rats show behavioral and physiological manifestations of fear, such as freezing, defecation, and increases in plasma corticosteroids ${ }^{20}$. The avoidance of the open arms occurs primarily because they prevent the rat from engaging in thigmotaxic behavior ${ }^{21,22}$. Thigmotaxis is a natural defensive response that keeps the rat in contact with a vertical surface, thereby avoiding predators ${ }^{23}$.

Each animal was placed in the central area of the maze facing one of the closed arms. The animals were observed for 5 min by a trained observer who sat quietly $1.5 \mathrm{~m}$ from the center of the maze and recorded the time spent in and the number of entries into each arm. An entry was recorded when the animal's four limbs had entered an arm. The observer was "blind" to the animal's condition.

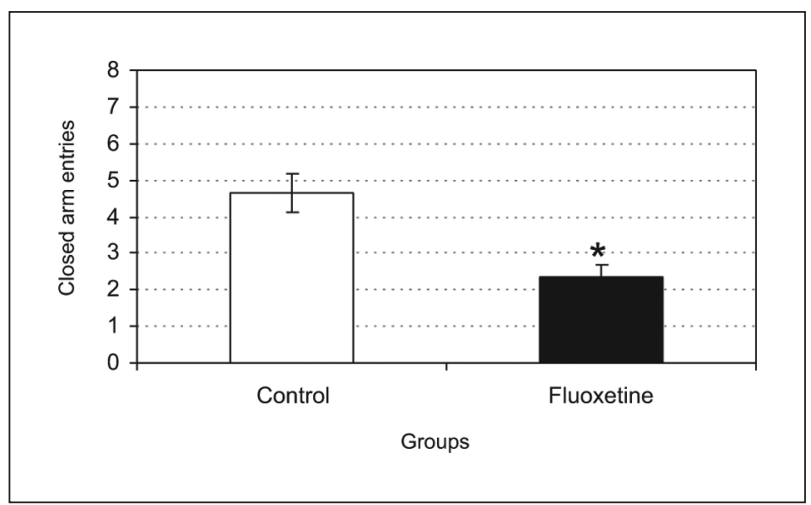

Fig 1. The number of entries in the closed arms. Evaluation in the elevated plus-maze. Fluoxetine chronic effect $(10 \mathrm{mg} / \mathrm{kg}$, sc, dissolved in saline solution, $1 \mathrm{ml} / \mathrm{kg}, \mathrm{n}=26$ ), during neonatal period compared to control group treated with saline ( $\mathrm{NaCl} 0,9 \%, 1 \mathrm{ml} / \mathrm{Kg}$, sc, daily, $n=26)$. The behavioral parameters (expresses mean \pm SEM) was analyzed by " $t$ " test. The significance level adopted for statistical tests was $p<0.05$.

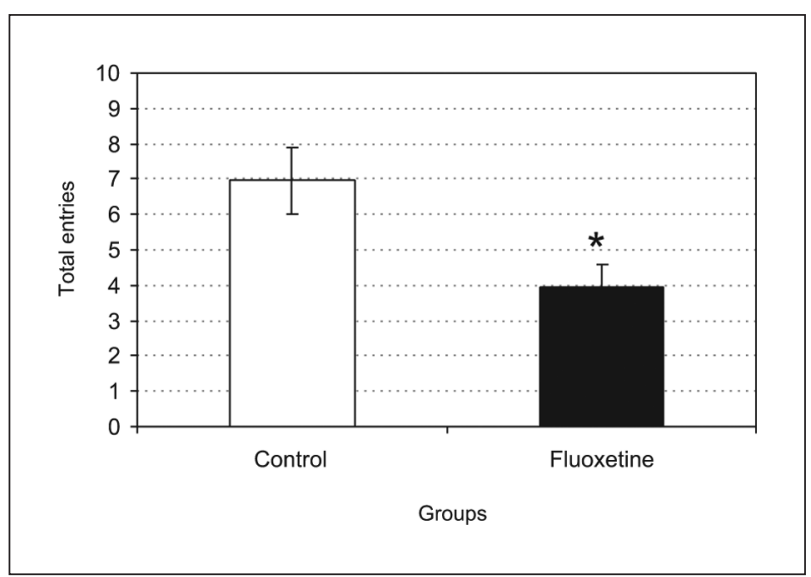

Fig 2. The total of entries. Evaluation in the elevated plus-maze. Fluoxetine chronic effect $(10 \mathrm{mg} / \mathrm{kg}$, sc, dissolved in saline solution, 1 $\mathrm{ml} / \mathrm{kg}, \mathrm{n}=26)$, during neonatal period compared to control group treated with saline ( $\mathrm{NaCl} 0,9 \%, 1 \mathrm{ml} / \mathrm{Kg}$, sc, daily, $n=26)$. The behavioral parameters (expresses mean \pm SEM) was analyzed by " $t$ " test. The significance level adopted for statistical tests was $p<0.05$. 
The anxiety evaluation was performed in two stages. In the first, the rats received a stimulus. This stimulus (an electric foot shock) consisted of a 1.6-mA - 2-s current pulse. In the second, the animals were naïve. The spent time in the open arms was anxiety index and the closed arms entries number and the total entries number were used as locomotor activity.

\section{Data analysis}

For each animal, the spent time in the open arms, the number of entries into the closed arms and the total number of entries (open+closed arms) were computed. The behavioral parameters (expresses mean \pm SEM) were analyzed by Student's " $t$ " test. The significance level adopted for statistical tests was $p<0.05$.

\section{RESULTS}

Compared to the control group, there was not statistical significance, in both stages, with time spent in the open arms of fluoxetine group. There were reductions within the fluoxetine group in the number of entries in the closed arms (2.35 $\pm 0.33, \mathrm{p}=0.001)$ (Fig 1) and in the total of entries (3.96 $\pm 0.61, p=0.010)$ (Fig 2) only in the second stage of the anxiety experiment, after the electric shock stimulus on the foot, when compared to the control group (4.65 $\pm 0.52 ; 6.96 \pm 0.94)$.

\section{DISCUSSION}

This study used fluoxetine in the neonatal period as a tool for manipulation of the serotonin neurotransmission. Besides the drug administration has been in the suckling period, there was also stress stimulus with incentive foot shock due the hypothesis that the behavioral effects of drugs that alter serotonin neurotransmission may be more apparent when the animal is more stressed ${ }^{24}$. The chronic administration of fluoxetine in rats, during the critical period of development of the nervous system, did not provoke alterations in the experimental anxiety profiles. However, the drug decrease locomotor activity in rats submitted to the foot shock stimulus before the elevated plus maze experiment.

There are studies demonstrating after acute administration of fluoxetine there is increase in extracellular serotonin in several subcortical brain regions due to reuptake blockade ${ }^{25}$. This extracellular $5-\mathrm{HT}$ seems to inhibit the firing of raphe neurons and thus to reduce $5-\mathrm{HT}$ release from nerve terminals ${ }^{8}$. It is often reported that the initial effect of fluoxetine administration in humans is an exacerbation of anxiety ${ }^{25}$. During chronic administration there is an increase of extracellular concentrations of 5-HT at cortical and subcortical levels. The long-term 5-HT reuptake blockade provokes desensitization of somatodendritic 5$\mathrm{HT}_{1 \mathrm{~A}}$ and terminal $5-\mathrm{HT}_{1 \mathrm{~B}}$ autoreceptors, leading to a disinhibitory effect on raphe neurons firing and to reduced feedback inhibition of 5-HT release ${ }^{25-28}$.
Acute or chronic treatment with fluoxetine in adult animal seems to increase the levels of 5-HT, facilitating anxiogenic effect in the experimental models of anxiety ${ }^{8}$. However, the manipulation of the serotoninergic neurotransmission still producing contradictory results in the anxiety studies using antidepressants ${ }^{29}$ and especially, when it involves fluoxetine and experimental models of anxiety ${ }^{18}$.

The animals treated with fluoxetine, in the neonatal period, submitted to foot electrical shock stimulus showed reductions with the fluoxetine group in the number of entries in the closed arms $(p<0.05)$ and in the total of entries $(p<0.05)$, when compared to the control groups. These results seem to indicate reduction of the locomotor activity, suggesting a sedative effect. This suppression could be due to predominant effects in the dorsal raphe reducing serotoninergic transmission in the forebrain ${ }^{25}$. This study did not find alterations in the anxiogenic or anxiolytic profiles of experimental anxiety.

Differently from our work, Ansorge et al. ${ }^{9}$ found anxiogenic effect in mice tested in the elevated plus-maze. However, this work corroborate Silva and Brandão ${ }^{19}$ that used fluoxetine (10 mg/Kg, PO) in chronic administration and did not find effect in none of the measures spacetime (entrance and exit of the arms or spent time in some of the elevated plus-maze's arms). Although both works have been accomplished with SSRI, using the elevated plus-maze, it is make necessary to present some methodological differences. The first of them refers the lineage of the animal and the second to the period from pharmacologic treatment. In the first work ${ }^{9}$, the animals were mice, while in our work the animals were rats and in the second ${ }^{19}$, fluoxetine administration did not happen in the neonatal period. Similar results, also using the elevated plus-maze, were presented before ${ }^{29}$.

Another question to be considered is the heterogeneity of symptoms presented by the anxiety disorder. The fluoxetine, for example, does not respond appropriately at treatment from widespread anxiety. However, it is used with effectiveness in compulsive obsessive disorder, social phobia, panic disturbance and nervous bulimy ${ }^{8}$.

The pharmacological treatment happened in the suckling period and the behavior tests were made in the adult age in this work, thus the present study showed the increase of serotonin due to the selective serotonin reuptake inhibition in different areas of the brain seem facilitate permanent behavior alterations.

\section{REFERENCES}

1. Chopin P, Moret C, Briley M. Neuropharmacology of 5-hydroxytryptamine 1B/1D receptor ligands. Pharmacol Therapeutics 1994;62:385-405.

2. Manhães-de-Castro R, Peregrino A, Sourgey E, Barreto Medeiros JM, Deiró TCBJ. Depression: repercussion in serotonergic system. Neurobiologia 1998;62:45-55. 
3. Rudolph R, Feiger AD. A double-blind, randomized, placebo-controlled trial of once-daily venlafaxine extended release (XR) and fluoxetine for the treatment of depression. J Affective Disord 1999;56:171-181.

4. Manhães-de-Castro R, Barreto Medeiros JM, Mendes da Silva C, et al. Reduction of intraspecific aggression in adult rats by neonatal treatment with a selective reuptake inhibitor. Braz J Med Biol Res 2001; 34:121-124.

5. Moeller F, Allen T, Cherek DR, Dougherty DM, Lane S, Swann AC. Ipsapirone neuroendocrine challenge: relationship to aggression as measured in the human laboratory. Psychiatry Res Ann NY Acad Sci 1998; 81:31-38

6. Jaiswal A, Upadhyay SN, Satyan KS, Bhattacharya SK. Behavioural effects of prenatal and postnatal undernutrition in rats. Indian J Exp Biol 1996;34:1216-1219.

7. Allikmets L, Matto V, Harro J. Do the antidepressants have anxiogenic action? Biol Psychiatry 1996;39:500-666.

8. Silva M, Alves CRR, Santarém EMM. Anxiogenic-like effect of acute and chronic fluoxetine on rats tested on the elevated plus-maze. Braz J Med Biol Res 1999;32:333-339.

9. Ansorge M, Zhou M, Lira A, Hen R, Gingrich JA. Early-life blockade of the 5-HT transporter alters emotional behavior in adult mice. Science 2004;306:879-881.

10. Fuller R, Wong DT. Serotonin reuptake blockers in vitro and in vivo. J Clin Psychopharmacol 1987;7(Suppl):S36-S43.

11. Blier P, Chaput Y, de Montigny C. Long-term 5-HT reuptake blockade, but not monoamine oxidase inhibition, decreases the function of terminal 5-HT autoreceptors: an electrophysiological study of the rat brain. Naunyn-Schmiedeberg's Arch Pharmacol 1988;337:246-254.

12. Mongeau R, Blier P, de Montigny $C$. The serotonergic and noradrenergic systems of the hippocampus: their interactions and the effects of antidepressant treatments. Brain Res Rev 1997;23:145-195.

13. Resnick O, Miller M, Forbes W, et al. Developmental protein malnutrition: influences on the central nervous system of the rat. Neurosci Biobehav Rev 1979;3:233-246.

14. Picanço-Diniz C, Araújo MS, Borba JMC, Guedes RCA. NADPH-diaphorase containing and biocytin-labelled axon terminals in the visual cortex of adult rats malnourished during development. Nutr Neurosci 1998;1:35-48

15. Manhães-de-Castro R, Cabral JE Filho, Costa JA, Costa FBR, Galindo MAC, Hecksher CA. Neonatal treatment with naloxone causes permanent hyperalgesia in rats. Braz J Med Biol Res 1993;26:747-751.
16. Manhães-de-Castro R, Barreto Medeiros JM, Mendes da Silva C, et al. Reduction of intraspecific aggression in adult rats by neonatal treatment with a selective reuptake inhibitor. Braz J Med Biol Res 2001;34: 121-124.

17. Morgane $\mathrm{P}$, Miller M, Kemper T, et al. The effects of protein alnutrition on the developing central nervous system in the rat. Neurosci Biobehav Rev 1978;2:137-230.

18. Sánchez C, Meier E. Behavioral profiles of SSRIs in animal models of depression, anxiety and aggression: are they all alike? Psychopharmacol 1997;129:197-205

19. Silva R, Brandão ML. Acute and chronic effects of gepirone and fluoxetine in rats tested in the elevated plus-maze: an ethological analyses. Pharmacol Biochem Behav 2000;65:209-216.

20. Griebel G, Rodgers RJ, Perrault G, Sanger DJ. Risk assessment behaviour: evaluation of utility in the study of 5-HT - related drugs in the rat elevated plus-maze test. Pharmacol Biochem Behav 1997;57:817-827.

21. Pellow S, Chopin P, File SE, Briley M. Validation of open:closed arm entries in an elevated plus-maze as a measure of anxiety in the rat. Neurosci Methods 1985;14:149-167.

22. Treit D. Anxiolytic effects of benzodiazepines and 5-HT1A agonists: animal models. In Rodgers JR, Cooper SJ (eds). 5-HT agonists, 5-HT3 antagonists and benzodiazepines. Their comparative behavioural Pharmacology. Chichester, UK: John Wiley Sons 1991:107-131.

23. Treit TDFM. Thigmotaxis as a test for anxiolytic activity in rats. Pharmacol Biochem Behav 1988;31:958-962.

24. Borsini F. Role of the serotonergic system in the forced swimming test. Neurosci Behav 1995;19:377-395.

25. Artigas F. 5 - HT and antidepressants: new views from microdialysis studies. Trends Pharmacol Sci 1993;14:262.

26. Hillegaart V, Hjorth $\mathrm{S}$. Median raphe, but not dorsal raphe application of the 5-HT1A agonist 8-OH-DPAT stimulations rat motor activity. Eur J Pharmacol 1989;160:303-307.

27. Blier P, de Montigny C, Chaput Y. Modification of the serotonina system by the antidepressant treatments: implications for the therapeutic response in major depression. J Clin Psychopharmacol 1987;7(Suppl):S24-S35.

28. Stanford S. Prozac: panacea or puzzle? Trends Pharmacol Sci 1996; 17:150-154.

29. Handley S, Mc Blane JW. Opposite effects of fluoxetine in two animal models of anxiety. Braz J Pharmacol 1993;107-446 (abstract).

30. Hiemke C, Härtter S. Pharmacokinetics of selective serotonin reuptake inhibitors. Pharmacol Therapeutics 2000;85:11-28. 